\title{
CHAGASIC MENINGOENCEPHALITIS: CASE REPORT OF A RECENTLY INCLUDED AIDS-DEFINING ILLNESS IN BRAZIL
}

\author{
Geraldine MADALOSSO, Alessandra C. GUEDES PELLINI, Marileide J. VASCONCELOS, Ana FREITAS RIBEIRO, Leonardo WEISSMANN, \\ Gilberto SILVA OLIVEIRA FILHO, Augusto C. PENALVA DE OLIVEIRA \& Jose E. VIDAL
}

\begin{abstract}
SUMMARY
Recently, reactivation of Chagas disease (meningoencephalitis and/or myocarditis) was included in the list of AIDS-defining illnesses in Brazil. We report a case of a 52-year-old patient with no history of previous disease who presented acute meningoencephalitis. Direct examination of blood and cerebrospinal fluid (CSF) showed Trypanosoma cruzi. CSF culture confirmed the diagnosis. Serological assays for T. cruzi and human immunodeficiency virus (HIV) were positive. Despite treatment with benznidazol and supportive measures, the patient died 24 hours after hospital admission. In endemic areas, reactivation of Chagas disease should always be considered in the differential diagnosis of meningoencephalitis among HIV-infected patients, and its presence is indicative of AIDS.
\end{abstract}

KEYWORDS: Chagas disease; Meningoencephalitis; Central nervous system; Epidemiology; Acquired immunodeficiency syndrome; Brazil.

\section{INTRODUCTION}

Chagas disease or American trypanosomiasis is endemic in Latin America and is caused by the flagellated protozoan Trypanosoma cruzi, and generally transmitted to humans by triatomine dejections. It can also be transmitted through blood transfusions and contaminated hemoderivates, needles and by syringe sharing among intravenous drug users, besides congenital transmission ${ }^{9,25}$.

Globally, Chagas disease represents the third most important tropical disease, after malaria and schistosomiasis ${ }^{20}$. In the Americas, there have been successful experiences regarding the control of Chagas disease vectorial transmission. Nevertheless, there are an estimated 11 million chronic cases of infection by T. cruzi $i^{13}$. In Brazil, some 3 to 5 million individuals are infected and, despite important progress achieved in recent years, there are still isolated reports of acute cases ${ }^{4,10}$, and also of blood transmission through intravenous drug users in several states and regions (Rio Grande do Sul, Minas Gerais, and Northeast) ${ }^{13,16,19,20,25}$. The progressive increase of Chagas disease cases in urban populations, as a result of massive migration from rural areas to major cities, associated to the interiorization of the epidemic infection caused by the human immunodeficiency virus (HIV) ${ }^{7}$, have created the conditions for emergence of a higher number of co-infection cases. Consequently, in the presence of severe immunodeficiency there is a possibility of chronic Chagasic infection reactivation, which is manifested by severe forms of neurological (75 - 90\% of cases) or myocardial (30\% of cases) involvement ${ }^{15,18-20,24,25,27}$.
Several studies have demonstrated the opportunistic nature of Chagas disease reactivation in AIDS patients ${ }^{9,12,14-18,28}$, which suggests that it should be considered an AIDS-defining illness ${ }^{1,11,20,26}$. Despite that established by the Centers for Disease Control and Prevention ${ }^{8}$, the Brazilian Ministry of Health has recently included reactivation of Chagas disease (meningoencephalitis and/or myocarditis) in the list of AIDSdefining events ${ }^{6}$. The potential advantages of this decision, include improved surveillance of HIV-associated Chagas disease, increased number of studies related to this co-infection, and provision of social benefits for the affected patients ${ }^{1}$.

In this study, we report a case of chagasic meningoencephalitis that led to the diagnosis of HIV infection, and which defined AIDS.

\section{CASE REPORT}

A 52-year-old heterosexual male was admitted to the hospital with a seven-day history of fever, headache and asthenia, and three days with altered level of consciousness. He had lost approximately $30 \mathrm{~kg}$ weight during the previous year. His medical history was unremarkable, as well as the use of intravenous drugs and blood transfusions. He had spent his childhood and adolescence in a rural area in Bahia but has lived continuously in an urban area of São Paulo for 33 years prior to becoming ill. On physical examination, he presented fever $\left(38.5^{\circ} \mathrm{C}\right)$, hypotension (90/60 mmHg), tachycardia, tachydyspneia, neck stiffness, and mental state alterations. Pulmonary auscultation revealed bilateral crepitation. He did not present papilledema, lateralizing signs (e.g. hemiparesis or 


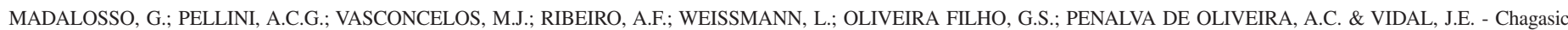
meningoencephalitis: case report of a recently included AIDS-defining illness in Brazil. Rev. Inst. Med. trop. S. Paulo, 46(4):199-202, 2004.

hemianoptic field defect), or focalizing signs (e.g. aphasia). A blood count revealed hemoglobin $=13.3 \mathrm{mg} / \mathrm{dL}$ and leukocytes $=10,200$ cells $/$ $\mathrm{mm}^{3}$ (92\% neutrophils, $7 \%$ lymphocytes, $1 \%$ monocytes). Biochemical test did not detect any alterations. Due to the severity of illness it was not possible to perform brain computed tomography (CT). A careful lumbar puncture was performed which found 16 cells ( $94 \%$ lymphocytes, $4 \%$ monocytes, $1 \%$ neutrophils, $1 \%$ eosinophils), protein $721 \mathrm{mg} / \mathrm{dL}$, and glucose $0 \mathrm{mg} / \mathrm{dL}$. Direct examination of CSF showed numerous forms of $T$. cruzi trypomastigote (Fig. 1), and CSF culture confirmed the diagnosis. Blood and CSF cultures for bacteria, fungi, and mycobacteria showed no growth. Serological assays for T. cruzi (indirect immunofluorescence, passive hemagglutination and enzyme linked immunoassay (ELISA)) were reagent. The xenodiagnosis was positive. A rapid test for HIV was reagent, which was later confirmed with ELISA and Western Blot. Benznidazol 5mg/kg/day twice daily was initiated. The patient was transferred to the Intensive Care Unit and placed under mechanical ventilation and hemodynamic support. Despite these measures, the patient developed neurological deterioration and multiple organ failure (respiratory insufficiency, oligoanuria, and shock) and died 24 hours after admission. Necropsy revealed findings compatible with brain edema, meningoencephalitis and an extensive area of necrosis in the right cerebellar region. Signs of dilated myocardiopathy and bilateral pulmonary congestion were observed. There were no findings of megacolon or megaesophagus.

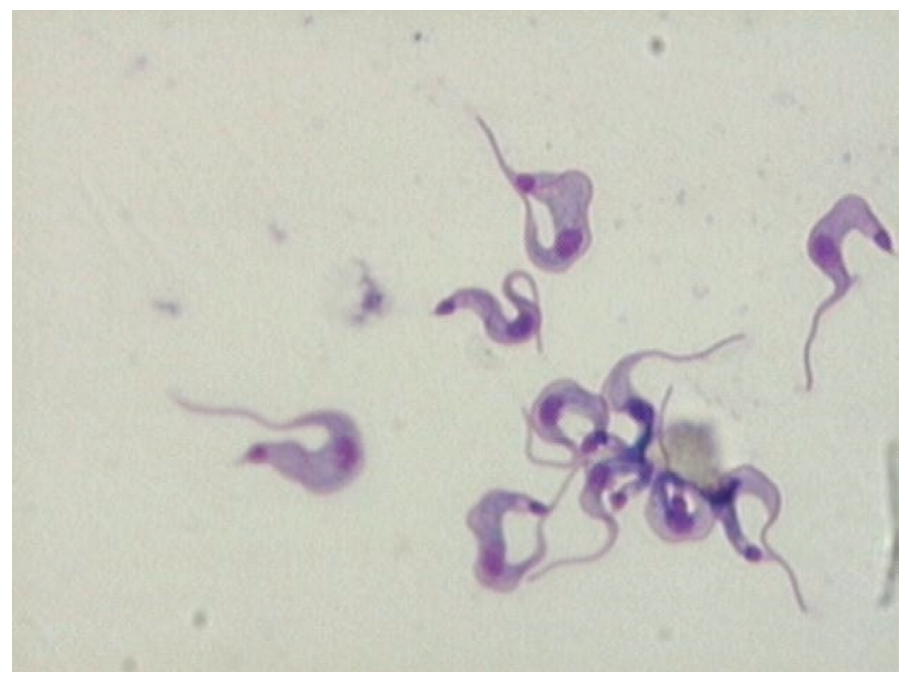

Fig. 1 - Trypanosoma cruzi trypomastigote forms in cerebrospinal fluid (Leishman, 40X).

\section{DISCUSSION}

DEL CASTILLO et al. ${ }^{12}$ reported in 1990, for the first time, the association of central nervous system (CNS) Chagas disease and HIV infection. FERREIRA et al. ${ }^{14}$, one year later, described the first case in Brazil.

To date, approximately 90 cases have been described of Chagas disease reactivation in AIDS patients, especially in Brazil and Argentina. However, a detailed description has only been given for a small number of these. The majority of cases were communicated in specialized congresses and symposiums ${ }^{18,20}$. The inclusion of Chagas disease reactivation in the list of AIDS-defining illnesses in Brazil should lead to a significant increase in the number of such case reports.

Brain expansive lesions, with or without meningoencephalitis, constitute the most frequent neurological presentation of Chagas disease reactivation in AIDS patients ${ }^{9,18}$. The clinical and radiological manifestations are unspecific and common to several CNS opportunistic diseases in AIDS patients. In our hospital (Institute of Infectious Diseases Emílio Ribas, São Paulo, Brazil), when meningeal or meningoencephalitis syndrome predominates, the main diagnoses are cryptococcosis, tuberculosis, and syphilis. When brain expansive lesion syndrome predominates, the main diagnoses include toxoplasmosis, tuberculosis (tuberculomas and/or abscesses), and CNS primary lymphoma (Vidal \& Penalva de Olivera, unpublished data). Consequently, it is necessary to maintain a high level of suspicion for Chagas disease. A detailed epidemiological history, including current and past residency in Chagas disease endemic areas, use of intravenous drugs, and blood or hemoderivative transfusion, is helpful in suggesting a diagnosis.

The laboratorial diagnosis of CNS Chagas disease reactivation included serology test for T. cruzi, direct examination of blood smears, neuroimages, and CSF analysis ${ }^{16,22}$. The greater or lesser contribution of the last two methods will depend upon the current neurological syndrome (brain expansive lesion or meningoencephalitis, respectively). It is important to emphasize that a positive result for blood culture and xenodiagnostic, should not be interpreted as absolute evidence of reactivation, in view of the positive results of these tests in chronic chagasic patients ${ }^{16}$.

Direct examination of CSF specimens could be a useful method for early and rapid diagnosis. A typical presentation of chagasic meningoencephalitis includes mild lymphocytosis $(<100$ cells $/ \mathrm{mL})$, low glucose levels, increased protein, and T. cruzi trypomastigote forms in the CSF centrifuged, or after staining techniques ${ }^{9,18}$.

The majority of AIDS patients with Chagas disease reactivation present $\mathrm{CD}^{+}$lymphocytes count $<200$ cells $/ \mu \mathrm{L}$, similar to those observed in other AIDS opportunistic neurological diseases ${ }^{18}$.

The current algorithms of brain expansive lesions management were carried out in Chagas disease non-endemic areas ${ }^{2,23}$. Classically, if the images show one or more expansive lesions, it is recommended to initiate anti-Toxoplasma specific therapy for 10 to 14 days. A lack of therapeutic response after this period indicates the need for carrying out stereotaxic biopsy. In certain circumstances, a surgical approach must be precipitated, such as in patients with negative IgG serology for T. gondii and single brain lesion, or when indicated at the therapeutic level ${ }^{2}$. However, high levels of suspicion of alternative cerebral toxoplasmosis diagnoses, as has been already reported in one case of cytomegaloviruses ${ }^{5}$ and in another of brain tuberculous abscess ${ }^{29}$, could also indicate the need for early biopsy. Interestingly, MONTERO et al. ${ }^{22}$ proposed a diagnostic algorithm for focal brain lesions in Chagas disease endemic areas.

Due to the high lethality, suspicion of Chagas disease reactivation must lead to more intensive diagnostic approaches, including early brain biopsy if it is not possible to reach the diagnostic through less invasive methods. 


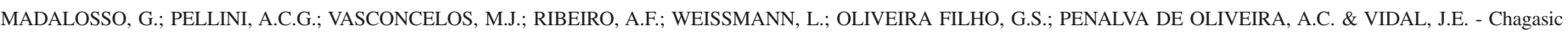
meningoencephalitis: case report of a recently included AIDS-defining illness in Brazil. Rev. Inst. Med. trop. S. Paulo, 46(4):199-202, 2004.

In recent years, the availability of molecular methods, applying the polymerase chain reaction (PCR) in CSF led to a shift from brain biopsy toward a "minimally invasive" approach of focal brain lesions in AIDS patients. This strategy helped to decrease the number of brain biopsies and augmented likelihood of in vivo diagnoses ${ }^{3}$. Recently, LAGES-SILVA et al. ${ }^{21}$ reported an AIDS patient with chagasic meningoencephalitis diagnosed by PCR assay in CSF. Further studies are necessary in order to evaluate the application of molecular diagnosis in this clinical setting.

The lethality of Chagas disease reactivation in AIDS patients is very high. The majority of cases present a fatal course within 10-20 days after diagnosis ${ }^{17}$. However, suitable treatment could help to improve survival rates. Additionally, several case reports suggest that concomitant use of antiretroviral therapies and subsequent immunological reconstitution are vital for a more favorable outcome ${ }^{16,17,28}$.

The inclusion of Chagas disease reactivation, as an AIDS-defining illness, should stimulate further physiopathological, epidemiological, and therapeutic studies on this important coinfection in the next few years. On the other hand, we expect that other endemic diseases, such as visceral leishmaniasis, could also be included.

In conclusion, Chagas disease reactivation must be considered in the differential diagnosis of meningoencephalitis, with or without focal brain lesions in AIDS patients. High levels of diagnostic suspicion, including epidemiological information (current or previous residency in Chagas disease endemic areas and/or use of intravenous drugs), clinical information (presence of concomitant myocardiopathy), and serological information (positive test for T. cruzi and/or negative for $T$. gondii), should lead to intensive diagnostic approaches. Emphasis should be placed on initiation of early therapy, which could reduce the case-fatality rate of this disease.

\section{RESUMO}

\section{Meningoencefalite chagásica: relato de caso de doença recentemente incluida como indicativa de AIDS no Brasil}

Recentemente, a reagudização da doença de Chagas (meningoencefalite e/ou miocardite) foi incluída na lista de doenças indicativas de aids no Brasil. Os autores relatam o caso de um paciente de 52 anos de idade, natural de área rural da Bahia e procedente de uma área urbana de São Paulo, sem história de doenças prévias e que apresentou meningoencefalite aguda. As sorologias e pesquisas parasitológicas diretas no sangue e no liquido cefalorraquideano (LCR) demonstraram presença de Trypanosoma cruzi, confirmando-se o diagnóstico mediante cultura do LCR. O teste rápido assim como os ELISA e Western Blot diagnosticaram infecção pelo vírus da imunodeficiência humana (HIV). Apesar do tratamento com benzonidazole e as medidas de suporte, o paciente faleceu 24 horas depois da admissão hospitalar. Em áreas endêmicas, a reagudização da doença de Chagas deve ser sempre considerada no diagnóstico diferencial das meningoencefalites e sua presença em pacientes com infecção pelo HIV é indicativa de aids.

\section{ACKNOWLEDGMENTS}

This study was supported by the Centro de Estudos Emílio Ribas, Instituto de Infectologia Emílio Ribas, São Paulo, SP, Brazil.

\section{REFERENCES}

1. ALBRECHT, H. - Redefining AIDS: towards a modification of the current AIDS case definition. Clin. infect. Dis., 24: 64-74, 1997.

2. AMERICAN ACADEMY OF NEUROLOGY - Evaluation and management of intracranial mass lesion in AIDS. Report of the Quality Standards Subcommittee of the American Academy of Neurology. Neurology, 50: 21-26, 1998.

3. ANTINORI, A.; AMMASSARI, A.; DE LUCA, A. et al. - Diagnosis of AIDS-related focal brain lesions: a decision-making analysis based on clinical and neuroradiologic characteristics combined with polymerase chain reaction assays in CSF. Neurology, 48: 687-694, 1997.

4. ARÊAS, F.C.; PINHEIRO, N.J.; BARROS, F.J. \& BORGES, I.B. - Doença de Chagas em fase aguda: relato de caso [abstract]. Rev. Soc. bras. Med. trop., 37(suppl. 1): 31-32, 2004.

5. BASSIL, H.F. \& WILLIAM, D.C. - Cytomegalovirus encephalitis in an HIV positive patient presenting with a cerebral mass lesion. AIDS Patient Care STDs, 11: 319321, 1997.

6. BRASIL/MINISTÉRIO DA SAÚDE/Secretaria de Vigilância em Saúde/Programa Nacional de DST e Aids - Critérios de definição de casos de AIDS em adultos e crianças. Brasilia, Ministério da Saúde, 2004. p. 1-53.

7. BRITO, A.M.; CASTILHO, E.A. \& SZWARCWALD, C.L. - AIDS e infecção pelo HIV no Brasil: uma epidemia multifacetada. Rev. Soc. bras. Med. trop., 34: 207-217, 2001.

8. CENTERS FOR DISEASE CONTROL - Revised classification system for HIV infection and expanded surveillance case definition for AIDS among adolescents and adults. M.M.W.R., 41(RR-17): 1-19, 1993.

9. CORTI, M. - AIDS and Chagas disease. AIDS Patients Care and STDs, 14: 581-588, 2000.

10. CUNHA, R.P.; GIL, L.H.; GARBERO, R.M. et al. - Doença de Chagas aguda na Amazônia: descrição de um caso autóctone na fronteira Brasil/Bolivia e avaliação do potencial endêmico da região [abstract]. Rev. Soc. bras. Med. trop., 37(suppl. 1): $31,2004$.

11. DE OLIVEIRA SANTOS, E.; DOS REIS CANELA, J.; GOMES MONCAO, H.C. \& GUEDES ROQUE, M.J. - Reactivation of Chagas' disease leading to the diagnosis of acquired immunodeficiency syndrome. Braz. J. infect. Dis., 6: 317-321, 2002.

12. DEL CASTILlO, M.; MENDOZA, G.; OVIEDO, J. et al. - AIDS and Chagas disease with central nervous system tumor-like lesion. Amer. J. Med., 88: 693-694, 1990.

13. DIAS, J.C.; SILVEIRA, A.C. \& SCHOFIELD, C.J. - The impact of Chagas disease control in Latin America: a review. Mem. Inst. Oswaldo Cruz, 97: 603-612, 2002.

14. FERREIRA, M.S.; NISHIOKA, S.A.; ROCHA, A. et al. - Acute fatal Trypanosoma cruzi meningoencephalitis in a human immunodeficiency virus-positive hemophiliac patient. Amer. J. trop. Med. Hyg., 45: 723-727, 1991.

15. FERREIRA, M.S. - A síndrome da imunodeficiência adquirida e as doenças endêmicas no Brasil. Rev. Soc. bras. Med. trop., 29: 531-535, 1996.

16. FERREIRA, M.S.; NISHIOKA, A.S.; SILVESTRE, M.T. et al. - Reactivation of Chagas' disease in patients with AIDS: report of three new cases and review of the literature. Clin. infect. Dis., 25: 1397-1400, 1997.

17. FERREIRA, M.S. - Infections by protozoa in immunocompromised hosts. Mem. Inst. Oswaldo Cruz, 95(suppl. 1): 159-162, 2000.

18. FERREIRA, M.S. \& BORGES, A.S. - Some aspects of protozoan infections in immunocompromised patients: a review. Mem. Inst. Oswaldo Cruz, 97: 443-457, 2002. 
MADALOSSO, G.; PELLINI, A.C.G.; VASCONCELOS, M.J.; RIBEIRO, A.F.; WEISSMANN, L.; OLIVEIRA FILHO, G.S.; PENALVA DE OLIVEIRA, A.C. \& VIDAL, J.E. - Chagasic meningoencephalitis: case report of a recently included AIDS-defining illness in Brazil. Rev. Inst. Med. trop. S. Paulo, 46(4):199-202, 2004.

19. FERREIRA, M.S.; LOPES, E.R.; CHAPADEIRO, E.; DIAS, J.C. \& OSTERMAYER, A.L. - Doença de Chagas. In: VERONESI, R. \& FOCACCIA, R., ed. Tratado de Infectologia. 2. ed. São Paulo, Atheneu, 2002. p. 1195-1233.

20. FREILIJ, H. - AIDS and Chagas. Avaliable at: http://www.fac.org.ar/fec/chagas/c15freil/ c15freil.htm. Accessed March 7, 2003.

21. LAGES-SILVA, E.; RAMIREZ, L.E.; SILVA-VERGARA, M.L. \& CHIARI, E. - Chagasic meningoencephalitis in a patient with acquired immunodeficiency syndrome: diagnosis, follow-up, and genetic characterization of Trypanosoma cruzi. Clin. infect. Dis., 34: 118-123, 2002

22. MONTERO, A.; COHEN, J.E.; MARTINEZ, D.P. \& GIOVANNONI, A.G. - Tratamiento empírico anti-Toxoplasma en SIDA y Chagas cerebral. Medicina (B. Aires), 58: 504-506, 1998

23. MONTOYA, J.G. \& REMINGTON, J.S. - Toxoplasma gondii. In: MANDELL, G.L.; BENNETT, J.E. \& DOLIN, R., ed. Mandell, Douglas, and Bennett's principles and practice of infectious diseases. 5. ed. Philadelphia, Churchill Livingstone, 2000. p. $2858-2888$.

24. PACHECO, R.S.; FERREIRA, M.S.; MACHADO, M.I. et al. - Chagas' disease and HIV co-infection: genotypic characterization of the Trypanosoma cruzi strain. Mem. Inst. Oswaldo Cruz, 93: 165-169, 1998.
25. PEDRO, R.J. - Doença de Chagas e síndrome da imunodeficiência adquirida: quantos estariam co-infectados no Brasil? [editorial]. J. bras. Aids, 2: 5-6, 2001

26. ROCHA, A.; FERREIRA, M.S.; NISHIOKA, S.A. et al. - Trypanosoma cruzi meningoencephalitis and myocarditis in a patient with acquired immunodeficiency syndrome. Rev. Inst. Med. trop. S. Paulo, 35: 205-208, 1993.

27. ROCHA, A.; MENEZES, A.C.; SILVA, A.M. et al. - Pathology of patients with Chagas' disease and acquired immunodeficiency syndrome. Amer. J. trop. Med. Hyg., 50: 261-268, 1994

28. SARTORI, A.M.; SHIKANAI-YASUDA, M.A.; AMATO NETO, V. \& LOPES, M.H. Follow up of 18 patients with human immunodeficiency virus infection and chronic Chagas disease, with reactivation of Chagas disease causing cardiac disease in three patients. Clin. infect. Dis., 26: 177-179, 1998.

29. VIDAL, J.E.; CIMERMAN, S.; SILVA, P.R. et al. - Tuberculous brain abscess in a patient with AIDS: case report and literature review. Rev. Inst. Med. trop. S. Paulo, 45: 111-114, 2003.

Received: 28 July 2004

Accepted: 11 August 2004 